\title{
Effect of land use conversion on soil organic carbon sequestration in the loess hilly area, loess plateau of China
}

Received: 10 August 2006/ Accepted: 25 September 2006/Published online: 13 December 2006 (C) The Ecological Society of Japan 2006

\begin{abstract}
Changes in land use may alter land cover, which results in carbon stock changes in biomass as well as in the soil. In China's loess plateau, vegetation restoration has been conducted since 1950 s to control soil erosion and improve the ecosystem, with significant investment of money and manpower. Despite these efforts, soil erosion has still been severe. To reduce soil erosion and improve land quality, China initiated another state-funded project, Grain-for-Green, in 1999 in the loess plateau. However, it is not clear how effective this newly initiated project will be. In this study, we evaluated the effect of land-use conversion on soil organic carbon (SOC) and the potential effect of the current project on SOC sequestration in the Anjiapo catchment area of the loess hilly area of the loess plateau in China. This evaluation is based on SOC measurements in cropland versus in other converted land use types. We found that SOC sequestration mainly occurred in the surface soil after land use conversion took place. Land use conversion from cropland to shrubland or wild grassland (i.e. undisturbed land) was better for SOC sequestration than tree plantation in the semi-arid loess hilly area. By using the land use change in the study area as a scenario, the potential contribution of land use change on SOC sequestration due to the Grain-for-Green projectwas estimated. It was found that this project in the loess plateau of China would be helpful for SOC sequestration ifsuccessfully implemented.
\end{abstract}

L. Chen $(\varangle) \cdot$ J. Gong $\cdot$ B. Fu $\cdot$ Z. Huang $\cdot$ Y. Huang

State Key Laboratory of Urban and Regional Ecology,

Research Center for Eco-Environmental Sciences,

Chinese Academy of Sciences, P.O. Box 2871,

Beijing 100085, People's Republic of China

E-mail: liding@rcees.ac.cn

Tel.: + 86-10-62943840

Fax: + 86-10-62923557

L. Gui

Dingxi Institute of Soil and Water Conservation,

Dingxi, Gansu Province 743000, People's Republic of China
Keywords Land use conversion - Soil organic carbon (SOC) concentration - Soil organic carbon density (SOCD) - Soil organic carbon sequestration · Grain-for-Green project · Loess hilly area $\cdot$ China

\section{Introduction}

Soils play an important role in the global carbon cycle. The soil carbon pool has been estimated at approximately 3.3 times the size of the atmospheric pool and 4.5 times the size of the biotic pool (Lal 2004a, b; Janzen 2004). As a common global issue, soil carbon sequestration is a natural, cost-effective, and environmentally friendly process, and soil carbon sequestration is also a strategy to achieve food security by improving soil quality (Lal 2004a). During the past two centuries, landuse practices, such as deforestation and tillage, have resulted in a net loss of soil carbon to the atmosphere. Recent concerns about rising carbon dioxide $\left(\mathrm{CO}_{2}\right)$ concentrations in the atmosphere have led to speculation that a large amount of carbon may be sequested back into the soil. This may happen through forestation and other land use conversions (Degryze et al. 2004).

Many studies have been conducted to assess the effects of land use changes on soil carbon stocks (Groenendijk et al. 2002; Murty et al. 2002; Paul et al. 2002; Scott et al. 2002; Degryze et al. 2004). During land use change, soil may act either as a carbon source or as a carbon sink, depending on the ratio between the inflows and outflows. Studies addressing soil organic carbon (SOC) dynamics when land is converted from one use to another would be valuable in improving our understanding and increasing our predictive capability over both short and long timescales (Post and Kwon 2000). Quantifying changes in soil carbon may be important for large-scale forestation or reforestation (Paul et al. 2002). Some studies have estimated the contribution of forestation to the global carbon cycle at both the regional (Paul et al. 2003; Wu et al. 2003; Evrendilek et al. 2004; Sakai et al. 2004) and global scales (Nilsson et al. 1995; Zhang and Xu 2003). Others were 
concerned with the characteristics of the current carbon pool of ecosystems (Li and Wang 1998; Chen and Li 2003; Pan et al. 2003; Zhang and $\mathrm{He} 2004$ ) and the effect of farm management on SOC (Brown and Lugo 1990; San José and Montes 2001; Manna et al. 2005; Olson et al. 2005; Cui et al. 2005). However, limited attention has been paid to the effect of land use conversion on soil carbon sequestration in China's loess plateau (Xu et al. 2003; Jia et al. 2004).

China's loess plateau, covering approximately $58 \times 10^{4} \mathrm{~km}^{2}$, is known for its long agricultural history and serious soil erosion. Since the 1950s substantial efforts to control soil erosion and restore vegetation have been made by Chinese government, for example, extensive tree plantation in the loess plateau in the 1970s, and integrated soil erosion control on the watershed scale in the 1980s and 1990s. Despite these efforts, soil erosion was still out of control, and vegetation had not grown up well by the late 1990s. In 1999, another project, Grain-forGreen, was initiated for soil erosion control and land quality improvement using widespread return of sloping cropland to other uses in the loess hilly area of the loess plateau. In this project, it was suggested to convert all croplands with slopes of greater than $15^{\circ}$ to green land, while the local farmers would receive grain from the government for the loss of food due to cropland decrease. Understanding the effect of this land-use conversion project on soil carbon sequestration is valuable for estimation of the global carbon cycle.

The objectives of this study were: (1) to analyze the effect of land use conversion on SOC concentration, (2) to analyze the effect of land use conversion on the soil organic carbon density (SOCD), and (3) to estimate the potential contribution of land use conversions on SOC sequestration in the study area, and also in the loess hilly area of the loess plateau of China.

\section{Materials and methods}

The study area

The study area is located in the Anjiapo catchment area, Dingxi, Gansu, China. It is at the western part of the loess plateau $\left(35^{\circ} 33^{\prime}-35^{\prime} \mathrm{N}, 104^{\circ} 38^{\prime}-40^{\prime} \mathrm{E}\right)$. The total area is $5.65 \mathrm{~km}^{2}$, ranging from 1,900 to $2,250 \mathrm{~m}$ above sea level. It belongs to a semi-arid temperate climate with annual mean rainfall of $427 \mathrm{~mm}$ (1951-2003). Approximately $56 \%$ of the rain falls in storms during the summer months (July to September) when severe soil erosion often occurs. The monthly mean maximum temperature is $34.3^{\circ}$ in July, and the monthly mean minimum temperature is $-27.1^{\circ}$ in January. The annual potential evapotranspiration is approximately $1,500 \mathrm{~mm}$. Soils in the study area originated from parent material of calcareous loess, with a low SOC concentration of less than $10 \mathrm{gC} \mathrm{kg}^{-1}$. These belong to the Calcic Cambisol group according to the Food and Agriculutre Organisation and United Nations Education Scientific and Cultural Organization (FAOUNESCO) soil classification system. More information on the soil features of the land use types in the loess hilly area is given in the literature (Zhang 1991; Li et al. 1992; Chang et al. 1999; Wang et al. 2001; Messing et al. 2003; Gong et al. 2006). Soil erosion in the study area is around $5.0-10.0 \times 10^{6} \mathrm{~kg} \mathrm{~km}^{-2} \mathrm{a}^{-1}$.

At present, the study area is covered by arable land, abandoned cropland, wild grassland, orchards (apricot/ apple/pear), shrubland and woodland. The major crops are spring wheat (Triticum aestivum L.), soybeans (Vigna angularis), potatoes (Solanum tuberosum L.), millet (Panicum miliaceum), and sorghum (Sorghum spp.). Major grasses include Stipa breviflora, Stipa bungeana, Thymis mongolicus and purple alfalfa (Medicago sativa). Artificial plantations include Chinese pine (Pinus tabulaeformis), oriental arborvitae (Platycladus orientalis), little leaf peashrub (Caragana microphylla) and sea buckthorn (Hippophea rhamnoides L.). Since the late 1970s, land use has changed a lot. A large decrease in cropland and a large increase of terraced cropland, wild grassland, shrubland, arbor woodland and residential land were found (Table 1).

In the loess plateau, sloping cropland is a widespread agricultural land use type, but its yield is low. In the study area, the crop yield is about $700-800 \mathrm{~kg} \mathrm{ha}^{-1}$ for spring wheat (T. aestivum) due to poor soil fertility and water availability (Zhao et al. 1995a, b; Chen et al. 2003; $\mathrm{Li}$ et al. 2004). This low-productivity system has existed for a long time.

Table 1 Land use change from 1978 to 2005 in the Anjiapo catchment area

\begin{tabular}{|c|c|c|c|c|c|}
\hline & \multicolumn{2}{|l|}{1978} & \multicolumn{2}{|l|}{2005} & \multirow{2}{*}{$\begin{array}{l}\text { Area } \\
\text { Increased }(\%)\end{array}$} \\
\hline & Area $\left(\mathrm{hm}^{2}\right)$ & Percentage $(\%)$ & Area $\left(\mathrm{hm}^{2}\right)$ & Percentage $(\%)$ & \\
\hline Cropland sloped & 258.82 & 45.82 & 0.00 & 0.00 & -45.82 \\
\hline Cropland terraced & 171.90 & 31.49 & 284.21 & 50.31 & +18.82 \\
\hline Cropland abandoned & 0.00 & 0.00 & 21.24 & 3.76 & +3.76 \\
\hline Residential land & 8.55 & 1.51 & 28.26 & 5.00 & +3.49 \\
\hline Road & 9.65 & 1.71 & 9.65 & 1.71 & 0.00 \\
\hline Orchard & 7.08 & 1.25 & 10.69 & 1.89 & +0.64 \\
\hline Arbor woodland & 27.91 & 4.94 & 48.14 & 8.52 & +3.58 \\
\hline Shrubland & 13.46 & 2.38 & 89.27 & 15.80 & +13.42 \\
\hline Wild grassland & 61.55 & 10.89 & 73.46 & 13.00 & +11.08 \\
\hline Total & 564.92 & & 564.92 & 100 & \\
\hline
\end{tabular}




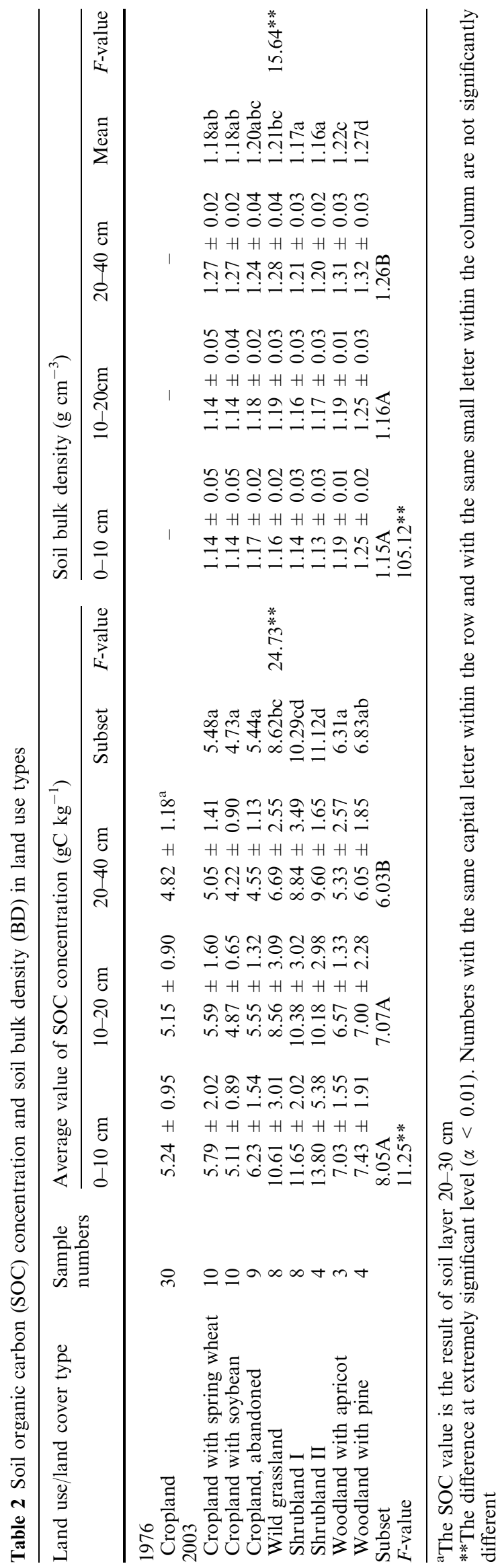

Wild grassland was usually found on the steep slopes where human activities were restricted (Chen et al. 2001). Shrubs and woods in the study area were planted for soil conservation in the late 1970s on sloping cropland. The major species are Robinia pseudoacacia L., P. tabulaeformis, Prunus armeriaca var.ansu, $C$. microphylla and $H$. rhamnoides L., as well as Platyclads orientalis. These species are also used as the pioneer trees during the ongoing Grain-for-Green project in the loess plateau. P. tabulaeformis, P. armeriaca var.ansu, $P$. orientalis, $R$. pseudoacacia $\mathrm{L}$. have poor coverage, poor understory and compacted soil in the study area due to water shortage. However, $C$. microphylla and $H$. rhamnoides $\mathrm{L}$. have low trunks, close cover and fertile soil. The abandoned cropland developed mainly in the period 1998-2001, and has some weeds growing on it.

After seed-sowing in April, crop coverage increased slowly in May, and reached its peak in June, lasting until late July, followed by rapid decline after harvest. Based on field surveys, it was found that the highest coverage of crops was no more than $50 \%$. Average coverage of shrubland, woodland and grassland from March to October was higher than for cropland.

In the first three years, the coverage of shrubland increased from 40 to $95 \%$, while it was $15-37 \%$ for the woodland. Herbaceous plants prevailed in the first three years, resulting in an increased coverage in grassland plots $(95 \%)$, after which the density decreased slightly $(85 \%)$. The coverage of pastureland decreased from 90 to $75 \%$, and after three years it was $35-50 \%$. In the study area, it was observed that shrubland and grassland had a better structure and humid environment other than the woodland.

The highest percentage of coverage was found in the shrubland. Natural herbaceous species grow well under $H$. rhamnoides L. However, neither herbaceous plants nor bushes colonized the plots of $P$. tabulaeformis. With successful invasion and colonization of large herbaceous species in the grassland, a Stipa community was formed with dense coverage of $S$. breviflora. Based on the survey of 10-year reforestation of $H$. rhamnoides L. and $P$. tabulaeformis, the thickness and density of litter layer were $4.5 \mathrm{~cm}$ and $7.6 \mathrm{~kg} \mathrm{~m}^{-2}$, and $0.5 \mathrm{~cm}$ and $200 \mathrm{~g} \mathrm{~m}^{-2}$, respectively. By contrast, organic matter levels in the soil under sea buckthorn were thicker than those under Chinese pine.

\section{Soil sampling and analysis}

Based on land use history, soil samples were analyzed from the following eight land use types: cropland with spring wheat ( $T$. aestivum), cropland with soybean $(V$. angularis), abandoned cropland ( $S$. bungeana, Artemisia salsoloides), wild grassland ( $S$. bungeana), shrubland I ( $C$. microphylla), shrubland II ( $H$. rhamnoides L.), apricot woodland ( $P$. armeriaca var.ansu), pine woodland ( $P$. tabulaeformis). Trees and shrubs were 
planted on the former sloping cropland in 1978. Abandoned cropland appeared during 1998-2001.

In April 2003, soil samples were collected at depths of $0-10,10-20$ and $20-40 \mathrm{~cm}$ from five points using a 20 by $5 \mathrm{~cm}$ soil auger; a ring tube was used to collect samples to determine the bulk density of the soil. The five replicated samples were manually homogenized, and major live plant material and gravels were removed. All the samples were air-dried and crushed to pass through a 2$\mathrm{mm}$ mesh. Fifty-gram subsamples were ground in a mortar to pass through a $0.25-\mathrm{mm}$ sieve. Samples were transported to the Institute of Soil and Water Conservation of the Chinese Academy of Sciences in Yangling, Shannxi province for determination of the SOC concentration. In total, 56 sites were chosen and $168 \mathrm{com}$ posite samples were collected (Table 2). The SOC was determined by using the oil bath- $\mathrm{K}_{2} \mathrm{CrO}_{7}$ titration method after digestion, and the soil bulk density (BD) was determined by the ring tube method suggested by the Chinese Editorial Committee of Soil Analysis (1996). Total soil carbon includes all belowground carbon, in both roots and charcoal. However, in this study, soil carbon was defined as that due to organic components. For practical purposes, only that in the fine-soil fraction $(<2 \mathrm{~mm})$ was considered. The average value of the SOC concentration and soil $\mathrm{BD}$ by layer was used in this study. The SOCD was calculated using the following equation:

$\mathrm{SOCD}_{i}=\mathrm{BD}_{i} \times \mathrm{SOC}_{i}$,

where $\mathrm{SOCD}_{i}$ is the carbon density in soil layer $i$ and its unit is $\mathrm{g} \mathrm{cm}^{-3}$; $\mathrm{BD}_{i}\left(\mathrm{~g} \mathrm{~cm}^{-3}\right)$ is soil BD of $i_{\mathrm{th}}$ soil layers; $\mathrm{SOC}_{i}\left(\mathrm{~g} \mathrm{~kg}^{-1}\right)$ is the concentration of SOC of $i_{\text {th }}$ soil layers.

\section{Statistical analysis}

To identify the effects of land use and soil depth on the SOC concentration, a variety of statistical analyses were conducted. Two-way analysis of variance (ANOVA) with land use type and soil layer as the main factors was employed to test the significance of mean differences (at an $\alpha$ value of 0.05 ). A univariate procedure was used to examine the normality of the distribution of the observed data before conducting ANOVA. After the ANOVA test indicated a significant effect at $P<0.05$, the means of each soil variable for each classifying factor were classified using the Duncan multiple-range procedure. The statistical analysis was undertaken using the general linear model (GLM) procedure of SPSS 11.0.

Comparison of the effect of land use conversion on SOC

A measurement of SOC for cropland was conducted in October 1976 by the Dingxi Institute of Soil and Water Conservation, Gansu, China. The SOC concentration of cropland was $5.24 \pm 0.95,5.15 \pm 0.90$, and $4.82 \pm$
$1.18 \mathrm{~g} \mathrm{~kg}^{-1}$ from the average of 30 sites in soil layers at depths of 0-10, 10-20 and 20-30 cm, respectively. These results gave a basis to compare the effect of land use conversion on SOC.

\section{Results}

Soil organic carbon concentration change

Two-way ANOVA indicated that land use and soil depth had a significant effect on SOC concentration (Table 2), and the interaction of land use and soil layer has no significant effect on soil organic carbon. In the following four groups: cropland/abandoned cropland/ apricot woodland, wild grassland/pine woodland,wild grassland/shrubland I, and shrubland I/shrubland II, no significant difference was found. Meanwhile, no significant difference was found between the soil layers $0-10$ and $10-20 \mathrm{~cm}$, whereas significant difference was found between the soil layers $0-10 / 10-20$ and $20-40 \mathrm{~cm}$. In our study, shrubland gave a higher SOC concentration compared with the other land use types. SOC concentration of shrubland II (Hippophae rhamnoides) was $13.80,10.18$, and $9.60 \mathrm{gC} \mathrm{kg}^{-1}$, respectively, in the $0-10$, 10-20, and $20-40 \mathrm{~cm}$ soil layers. Shrubland I (C. microphylla) had an SOC concentration of $11.65,10.38$, $8.84 \mathrm{gC} \mathrm{kg}^{-1}$, respectively, in the corresponding soil layers. Arable land had the lowest SOC concentration of about 5.79, 5.59, $5.05 \mathrm{gC} \mathrm{kg}^{-1}$ for spring wheat (T. aestivum), and $5.11,4.87,4.22 \mathrm{gC} \mathrm{kg}^{-1}$ for soybean ( $V$. angularis), respectively, in the $0-10,10-20$, and $20-40 \mathrm{~cm}$ soil layers. SOC concentration in abandoned cropland and wild grassland was quite high except in woodland.

Soil organic carbon concentration decreased as the depth increases (see Table 2). Compared with the SOC in the surface soil, shrubland II (H. rhamnoides L.) showed a drastic decrease from the surface soil $(0-$ $10 \mathrm{~cm})$ to the deep soil layer $(20-40 \mathrm{~cm})$. This was followed by shrubland I (C. microphylla), wild grassland, abandoned cropland, apricot woodland, pine woodland, cropland with spring wheat, and cropland with soybean.

\section{Soil bulk density}

Soil BD was largely affected by land use/land cover and soil depth (Table 2). Two-way ANOVA showed that land use and soil layer had a significant effect on soil bulk density. The land use types are classified into the following four groups: cropland/abandoned cropland/ shrubland I/shrubland II, cropland/abandoned cropland/wild grassland, abandoned cropland/wild grassland/apricots woodland, and pine woodland. However, the difference of soil BD among the land use types was found to be smaller than for the SOC concentration, and soil BD increased with depth. Two-way ANOVA showed that no significant difference remained between 
the $0-10$ and $10-20 \mathrm{~cm}$ soil layers. In general, pine woodland ( $P$. tabulaeformis) had the highest soil bulk density, of $1.25,1.25$ and $1.32 \mathrm{~g} \mathrm{~cm}^{-3}$, correspondingly to the $0-10,10-20$ and $20-40 \mathrm{~cm}$ soil layers. Shrubland II (H. rhamnoides L.) had the lowest soil bulk density of about $1.13,1.17$ and $1.20 \mathrm{~g} \mathrm{~cm}^{-3}$, in the corresponding soil layers. The soil BD of the other land use types was in between that of pine woodland and shrubland II.

\section{Soil organic carbon density}

As for the SOCD (see Table 3 and Fig. 1a), shrubland had the highest value of about 15.59, 11.91, $11.62 \mathrm{~g} \mathrm{~cm}^{-3}$ for $H$. rhamnoides $\mathrm{L}$. in the $0-10,10-20$, and $20-40 \mathrm{~cm}$ soil layers, respectively, and $13.28,12.03$, $10.70 \mathrm{gC} \mathrm{cm}^{-3}$ for C. microphylla. Cropland had the lowest value, and woodland had a moderate SOC density (Table 3 ). However, wild grassland had a relatively high SOC density of $12.31,10.19,8.56 \mathrm{gC} \mathrm{cm}^{-3}$, respectively, in the $0-10,10-20$ and $20-40 \mathrm{~cm}$ soil layers.

Soil organic carbon density decreased with depth increase (Fig. 1b). From Fig. 1b, it was found that shrubland II (H. rhamnoides L.) showed a drastic decrease in SOCD from $15.59 \mathrm{gC} \mathrm{cm}^{-3}$ in the surface soil $(0-10 \mathrm{~cm})$ to $11.62 \mathrm{gC} \mathrm{cm}^{-3}$ in the soil layer $(20-40 \mathrm{~cm})$. This was followed by wild grassland, shrubland I, abandoned cropland, apricot woodland; pine woodland, cropland with spring wheat, and cropland with soybean.

\section{Discussion}

Soil organic carbon concentration change with land use conversion

Generally, a new equilibrium (or near equilibrium) was reached between residue inputs and decomposition after vegetation restoration. The time taken for the equilibrium state to develop was estimated to be 10 years following natural forest succession in Nigeria $(0-10 \mathrm{~cm}$, Aweto 1981), 30 years under eucalyptus and pine plantations in Congo $(0-5 \mathrm{~cm}$, Trouve et al. 1996), 40-60 years under pine-oak stands in Massachusetts (0-15 cm, Compton et al. 1998), and more than 60 years following natural forest succession in Minnesota
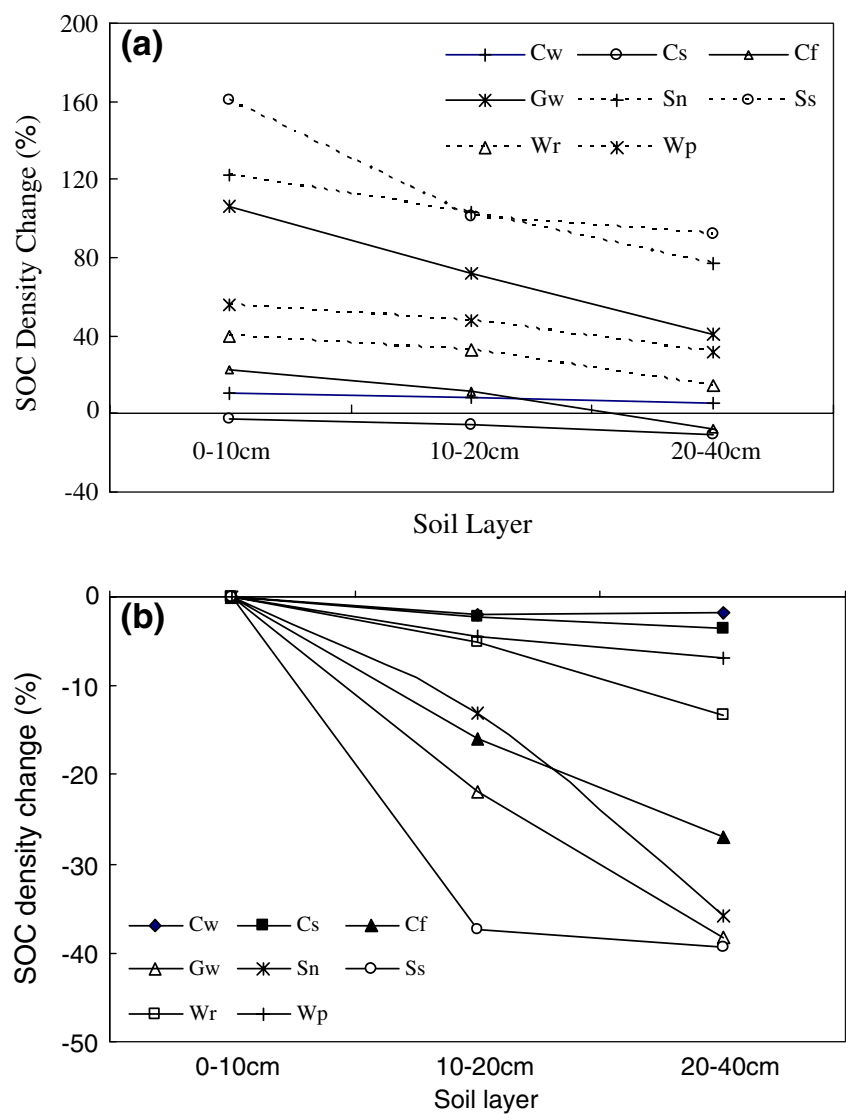

Fig. 1 Comparison of soil organic carbon density after land use change. a The land use types were compared with cropland in 1976; b the lower soil layers were compared with the surface soil layer. $C w$ Cropland with spring wheat (Triticum aestivum); Cs cropland with soybean (Vigna angularis); $C f$ abandoned cropland (Stipa bungeana, Artemisia salsoloides); $G w$ wild grassland (S. bungeana); Sn shrubland I (Caragana microphylla); Ss shrubland II (Hippophea rhamnoides L.); $W r$ woodland with apricot (Prunus armeriaca var.ansu); $W p$ woodland with pine (Pinus tabulaeformis)
Table 3 Soil organic carbon density (SOCD) by land use type

*The value of soil BD of cropland in 2003 was used when calculating the SOCD of cropland in 1976

\begin{tabular}{|c|c|c|c|}
\hline \multirow[t]{2}{*}{ Land use type } & \multicolumn{3}{|c|}{ Soil organic carbon density $\left(\mathrm{mgC} \mathrm{cm}^{-3}\right)$} \\
\hline & $0-10 \mathrm{~cm}$ & $10-20 \mathrm{~cm}$ & $20-40 \mathrm{~cm}$ \\
\hline 1976 & & & \\
\hline $\begin{array}{l}\text { Cropland* } \\
2003\end{array}$ & $5.97 \pm 1.08$ & $5.87 \pm 1.03$ & $6.12 \pm 1.50$ \\
\hline Cropland with spring wheat & $6.60 \pm 2.30$ & $6.37 \pm 1.82$ & $6.41 \pm 1.79$ \\
\hline Cropland with soybean & $5.83 \pm 1.01$ & $5.55 \pm 0.74$ & $5.49 \pm 1.14$ \\
\hline Cropland, abandoned & $7.29 \pm 1.80$ & $6.55 \pm 1.56$ & $5.64 \pm 1.40$ \\
\hline Wild grassland & $12.31 \pm 3.49$ & $10.19 \pm 3.68$ & $8.56 \pm 3.26$ \\
\hline Shrubland I (Caragana microphylla) & $13.28 \pm 2.30$ & $12.03 \pm 3.50$ & $10.70 \pm 4.22$ \\
\hline Shrubland II (Hippophea rhamnoides L.) & $15.59 \pm 6.08$ & $11.91 \pm 3.49$ & $11.62 \pm 2.00$ \\
\hline Woodland with apricot & $8.37 \pm 1.84$ & $7.82 \pm 1.58$ & $6.98 \pm 3.67$ \\
\hline Woodland with pine & $9.29 \pm 2.39$ & $8.75 \pm 2.85$ & $7.99 \pm 2.44$ \\
\hline
\end{tabular}


(0-10 cm, Zak et al. 1990). In our study, shrubs and trees had grown for 25 years since plantation. The highest SOC in shrubland implied that the SOC may improve when cropland was converted into shrubland. However, restoration of trees in the semi-arid loess hilly area gave a lower SOC value than shrubland. This was largely because of the microclimate. The low stock and close canopy of the shrubland created a moist environment while woodland has open land. It was reported that climate had a significant effect on soil carbon change $(<30 \mathrm{~cm})$ following forestation (Paul et al. 2002). SOC could be greatly increased in tropical and subtropical regions, and to a lesser extent, continental moist regions. In contrast, there was a slight decrease in the surface soil carbon in temperate/Mediterranean climates. Our results show that the low SOC in woodland could be attributed to low residue input. In the study area, microorganism activity is also poor because of the arid environment.

Land use conversion may affect the SOC concentration distribution in the soil profile. In our study, the SOC in the surface soil was obviously higher than that in the deep soil for shrubland and wild grassland. However, a small difference in SOC concentration was found between the surface and the deep soil in cropland, and a moderate difference in woodland. This was because of the high residue input in the surface soil (Li et al. 1992; Wu et al. 2004; Liu et al. 2005). However, at increasing depths, few residues were introduced, and nutrients were taken in by the root system from the soil for plant photosynthesis.

Soil organic carbon concentration increased when cropland was converted into other land use types. Compared with cropland in 1976, SOC concentration in the surface soil $(0-10 \mathrm{~cm})$ increased by $163 \%$ when it was converted into shrubland II (H. rhamnoides L.), by $122 \%$ for shrubland I (C. microphylla), by $102 \%$ for wild grassland ( $S$. bungeana). This suggested that land use conversion from cropland to other land use types may help improve SOC and soil quality. However, SOC increase was relatively lower when cropland was converted into woodland. Simultaneously, the SOC increase was smaller with increasing depth. This indicated that culti- vation would result in an SOC decrease. However, the decrease would became smaller as depth increases.

Soil organic carbon density change with increasing soil depth

Soil organic carbon density decreased with depth. This was attributed to the distribution of roots in the soil and associated soil processes. Johnson et al. (2001) reported that the largest differences in soil nutrient between secondary and the primary forests soils occurred in the 0 $5 \mathrm{~cm}$ depth. From Fig. 1, we found a dramatic decrease in the SOC density in the soils of wild grassland, abandoned cropland, and shrubland except in woodland. This was because of the high accumulation of plant residues and better humic process in the surface soil of shrubland and grassland (Li et al. 1992; Wu et al. 2004; Liu et al. 2005). However, this process under woodland was poor due to low soil moisture. Meanwhile, removal of the dead branches from woodland ground by local farmers for heating may be another reason for the low residue input into the soil.

Soil organic carbon density difference between the cropland and the other converted land use types became smaller with depth. The SOC density changed from a range of 5.83-15.59 $\mathrm{gC} \mathrm{kg}^{-1}$ in the surface soil $(0-10 \mathrm{~cm})$ to a range of $5.49-11.62 \mathrm{gC} \mathrm{kg}^{-1}$ in the lower soil layer $(20-40 \mathrm{~cm})$. Degryze et al. (2004) also found that most soil carbon changes occurred in the topsoil layer $(0$ $7 \mathrm{~cm})$ whereas soil carbon $(0-50 \mathrm{~cm})$ did not change significantly after poplar forestation. In our study, the SOC density decreased dramatically in the soil layer (10$20 \mathrm{~cm}$ ) compared with the surface soil, and then slow down when it reached $20-40 \mathrm{~cm}$, in particular for shrubland II (H. rhamnoides L.), apricot woodland ( $P$. armeriaca var.ansu) and pine woodland (P. tabulaefor$m i s)$. This indicated that the topsoil was more active at sequestering carbon after land use alteration. Furthermore, the large and rapid changes in the SOC density after land use conversion indicated that there was considerable potential to enhance soil carbon sequestration in the loess hilly area of China.
Table 4 Contribution of land use conversion to SOC sequestration in the Anjiapo catchment area

*The area of shrubland in 2005 was divided into I and II by half; **the SOC sequestration of orchard was supposed to be the same as woodland with apricot since the apricot was normally used as a fruit tree in the loess area; ***the SOC sequestration of arbor woodland was considered to be the same as woodland with pine

\begin{tabular}{|c|c|c|c|}
\hline Land use types & $\begin{array}{l}\text { SOCD in the } \\
\text { soil layer } 0-40 \mathrm{~cm} \\
\left(\mathrm{gC} \mathrm{cm}^{-2}\right)\end{array}$ & $\begin{array}{l}\text { Land use change } \\
\text { in area from } 1976 \\
\text { to } 2005\left(\mathrm{hm}^{2}\right)\end{array}$ & $\begin{array}{l}\text { SOC pool } \\
\text { change }\left(10^{8} \mathrm{gC}\right)\end{array}$ \\
\hline \multicolumn{4}{|l|}{1976} \\
\hline Cropland & $0.30 \pm 0.06$ & & \\
\hline \multicolumn{4}{|l|}{2003} \\
\hline Cropland with spring wheat & $0.32 \pm 0.10$ & -146.51 & -3.24 \\
\hline Cropland with soybean & $0.28 \pm 0.05$ & 0 & 0 \\
\hline Cropland abandoned & $0.32 \pm 0.08$ & 21.24 & 0.36 \\
\hline Wild grassland & $0.50 \pm 0.17$ & 11.91 & 2.36 \\
\hline Shrubland I (C. microphylla $)^{*}$ & $0.59 \pm 0.18$ & 37.905 & 10.91 \\
\hline Shrubland II (H. rhamnoides L.)* & $0.63 \pm 0.17$ & 37.905 & 12.39 \\
\hline Woodland with apricot** & $0.38 \pm 0.12$ & 3.61 & 0.29 \\
\hline Woodland with pine*** & $0.43 \pm 0.13$ & 20.23 & 2.59 \\
\hline Total & & & 25.45 \\
\hline
\end{tabular}


Table 5 Potential contribution of land use conversion on SOC sequestration in the loess hilly area of China

\begin{tabular}{llll}
\hline Area concerned & Cropland conversion type & Area $\left(\mathrm{hm}^{2}\right)$ & SOC pool change $\left(10^{8} \mathrm{gC}\right)$ \\
\hline Anjiapo catchment area & Cropland converted since 1978 & 146.51 & 25.45 \\
The loess hilly area* & Cropland over $25^{\circ}$ to be converted & $121 \times 10^{4}$ & $21.02 \times 10^{4}$ \\
& Cropland over $15^{\circ}$ to be converted & $204.7 \times 10^{4}$ & $35.55 \times 10^{4}$ \\
\hline
\end{tabular}

*The land use conversion was supposed to be conducted as in the model Anjiapo catchment area

Soil organic carbon sequestration by land use conversion

Land use conversion made varying contribution to SOC increase in the study area. In our study, although woodland showed the largest area increase from 1978 to 2005 , its contribution to SOC sequestration was limited. Shrubland, including $C$. microphylla and $H$. rhamnoides L., was the largest contributor to SOC sequestration. The order of contributions of land use conversion in the study area since 1978 was: shrubland II $($ H. rhamnoides L.) $>$ shrubland I $(C$. microphylla $)>$ woodland $(P$. tabulaeformis/Platcladus orientalis $)>$ wild grassland $>$ abandoned cropland $>$ orchard ( $P$. orientalis/Malus pumila/Pyrus sp.). This result, from another point of view, indicated that conversion from cropland to woodland was not supported, and that shrubland, as well as cropland abandonment (land closure) should be encouraged in the semi-arid loess hilly area (Table 4).

Grain-for-Green project (i.e., land use conversion), currently implemented in the loess hilly area, will contribute to the global carbon cycle while improving the regional environment. The loess hilly area covers approximately half of the loess plateau, and the land use of about $121 \times 10^{4}$ ha of cropland with slopes greater than $25^{\circ}$, and $83.7 \times 10^{4}$ ha of cropland with slopes of $15-25^{\circ}$, was planned to be changed during the Grain-forGreen project (Xu and Tian 2004). If all the croplands with slopes larger than $25^{\circ}$ were converted into other land uses as in the study area, SOC sequestration in the soil layer $(0-40 \mathrm{~cm})$ would be increased by $21.02 \mathrm{TgC}$. If all the sloping croplands steeper than $15^{\circ}$ were changed into other land use types, SOC in the soil layer $(0$ $40 \mathrm{~cm}$ ) would be increased by $35.55 \mathrm{TgC}$ (Table 5). This will be helpful for the global carbon balance.

\section{Conclusions}

We found that, compared with the other land use conversions, the conversion from cropland to shrubland was more favorable for soil carbon sequestration in the semiarid loess hilly area. This conclusion is different from some other studies, which supported arbor tree plantation. We also found that wild grassland, i.e. land abandonment, might be a promising choice in the loess hilly area for soil erosion control and soil quality improvement.
We found that soil carbon sequestration occurred mainly in the surface soil after land use conversion. There was no significant difference between the cropland and the other land use types in the lower soil layers. In addition, the SOCD declined dramatically with depth. These findings suggested that a large potential for improved SOC exists in the loess hilly area of China by land use adjustment, particularly in the topsoil.

Land use conversion in the study area made a contribution to SOC sequestration by the order: shrubland II $(H$. rhamnoides L.) $>$ shrubland I (C. microphylla) $>$ woodland $(P$. tabulaeformis $/ P$. orientalis $)>$ wild grassland $>$ abandoned cropland $>$ orchard $(P$. orientalis/M. pumila/Pyrus sp.), although the woodland was the largest by area increase from 1978 to 2005 .

The ongoing project, Grain-for-Green in the loess hilly area, aiming to reduce soil erosion and improve land quality, will have an effect on SOC sequestration. If all croplands with slopes larger than $25^{\circ}$ were changed into other land use types as in the Anjiapo catchment area, the potential contribution to SOC sequestration in the loess hilly area would be $21.02 \mathrm{TgC}$, and it would be $35.55 \mathrm{TgC}$ if all the croplands with slopes larger than $15^{\circ}$ were altered. This will be helpful for the global carbon cycle and balance.

Acknowledgments Financial support for this research came from the Natural Science Foundation of China $(90502007 ; 40321101)$ and the National Advanced Project of the 10th 5-year Plan of China (2004BA606A-03). The authors would like to thank the Institute of Soil and Water Conservation of the Chinese Academy of Sciences for conducting laboratory analysis, and the Dingxi Institute of Soil and Water Conservation for fieldwork support and data collection. Sincere thanks are given to Prof. Yang X.J., Department of Geography of Florida State University for his assistance with the English text. We would also like to express our thanks to the three anonymous reviewers for their valuable comments.

\section{References}

Aweto AO (1981) Secondary succession and soil fertility restoration in south-western Nigeria. II. Soil fertility restoration. J Ecol 69:609-614

Brown S, Lugo AE (1990) Effects of forest clearing and succession on the carbon and nitrogen concentration of soils in Puerto Rico and US Virgin Islands. Plant Soil 124:53-64

Chang QR, An SS, Liu J, Wang B, Wei YS (1999) Study on benefits of recovering vegetation to prevent land deterioration on loess plateau (Chinese with English abstract). J Soil Erosion Soil Water Conserv 5(4):6-9

Chen XW, Li BL (2003) Change in soil carbon and nutrient storage after human disturbance of a primary Korean pine forest in Northeast China. For Ecol Manage 186:197-206 
Chen LD, Wang J, Fu BJ, Qiu Y (2001) Land use change in a small catchment of northern Loess Plateau, China. Agric Ecosyst Environ 86:163-172

Chen QB, Wang KQ, Qi S, Sun LD (2003) Soil and water erosion in its relation to slope field productivity in hilly gully areas of the Loess Plateau (Chinese with English abstract). Aata Ecol Sin 23(8): 1463-1469

Chinese Editorial Committee of Soil Analysis (1996) Soil physical and chemical analysis and description of soil profile (in Chinese). China State Standards Press, Beijing

Compton JE, Boone RD, Motzkin G, Foster DR (1998) Soil carbon and nitrogen in a pine-oak sand plain in central Massachusetts: role of vegetation and land-use history. Oecologia 116:536-542

Cui XY, Wang YF, Niu HS, Wu J, Wang SP, Schnug E, Rogasik J, Fleckenstein J, Tang YH (2005) Effect of long-term grazing on soil organic carbon concentration in semiarid steppes in Inner Mongolia. Ecol Res 20:519-527

Degryze S, Six J, Paustian K, Morris S, Paul EA, Merckx R (2004) Soil organic carbon pool changes following land-use conversion. Glob Change Biol 10:1120-1132

Evrendilek F, Celik I, Kilic S (2004) Changes in soil organic carbon and other physical soil properties along adjacent Mediterranean forest, grassland, and croplands in Turkey. J Arid Environ 59:743-752

Gong J, Chen LD, Fu BJ, Huang YL, Huang ZL, Peng HJ (2006) Effect of land use on soil nutrients in the loess hilly area of the loess plateau, China. Land Degrad Dev (in press) www.interscience.wiley.com, DOI: 10.1002/ldr.701

Groenendijk FM, Condron LM, Rijkse WC (2002) Effect of afforestation on organic carbon, nitrogen, and sulfur concentration in New Zealand hill country soils. Geoderma 108:91-100

Janzen HH (2004) Carbon cycling in earth systems - a soil science perspective. Agric Ecosyst Environ 104:399-417

Jia SW, He XB, Chen YM (2004) Effect of land abandonment on soil organic carbon sequestration in loess hilly areas (Chinese with English abstract). J Soil Water Conserv 18(3):78-80

Johnson CM, Vieira ICG, Zarin DJ, Frizano J, Johnson AH (2001) Carbon and nutrient storage in primary and secondary forests in eastern Amazonia. For Ecol Manage 147:245-252

Lal R (2004a) Soil carbon sequestration to mitigate climate change. Geoderma 123:1-22

Lal R (2004b) Soil carbon sequestration impacts on global climate change and food security. Science 304:1623-1627

Li ZP, Wang XJ (1998) Simulation of soil organic carbon dynamic after changing land use pattern in hilly red soil red region (Chinese with English abstract). Chin J Appl Ecol 9:365-370

Li XL, Tian JY, Zhang CE (1992) A study on effects of different types of forest on the loess plateau on physical properties of soil (Chinese with English abstract). Sci Silvae Sin 28(2):98-106

Li FM, Song QH, Jjemba PK, Shi YC (2004) Dynamics of soil microbial biomass $\mathrm{C}$ and soil fertility in cropland mulched with plastic film in a semiarid agro-ecosystem. Soil Biol Biochem 36:1893-1902

Liu MY, An SS, Chang QR (2005) Features of soil organic carbon under different land use in mountain area of southern Ningxia (Chinese with English abstract). Res Soil Water Conserv 12(3):47-49

Manna MC, Swarup A, Wanjari RH, Ravankar HN, Mishra B, Saha MN, Singh YV, Sahi DK, Sarap PA (2005) Long-term effect of fertilizer and manure application on soil organic carbon storage, soil quality and yield sustainability under sub-humid and semi-arid tropical India. Field Crops Res 93:264-280

Messing I, Chen LD, Hessel R (2003) Soil conditions in a small catchment on the Loess Plateau in China. Catena 54(1-2):45-58

Murty DM, Kirschbaum UF, Mcmurtrie RR, Mcgilvray H (2002) Does conversion of forest to agricultural land change soil carbon and nitrogen? A review of the literatures. Glob Change Biol $8: 105-123$
Nilsson S, Schopfhauser W, Hoen HF, Solberg B (1995) The carbon-sequestration potential of a global afforestation program. Clim Change 30:267-293

Olson KR, Lang JM, Ebelhar SA (2005) Soil organic carbon changes after 12 years of no-tillage and tillage of Grantsburg soils in southern Illinois. Soil Tillage Res 81:217-225

Pan GX, Li LQ, Wu LS, Zhang XH (2003) Storage and sequestration potential of topsoil organic carbon in China's paddy soils. Glob Change Biol 10:79-92

Paul KI, Polglase PJ, Nyakuengama JG (2002) Change in soil carbon following afforestation. For Ecol Manage 168:241-257

Paul KI, Polglase PJ, Richards GP (2003) Predicted change in soil carbon following afforestation or reforestation, and analysis of controlling factors by linking a $\mathrm{C}$ accounting model (CAMFor) to models of forest growth (3PG), litter decomposition (GENDEC) and soil C turnover (RothC). For Ecol Manage 177:485501

Post WM, Kwon KC (2000) Soil carbon sequestration and land-use change: processes and potential. Glob Change Biol 6:317-327

Sakai RK, Fitzjarrald DR, Moraesw OLL, Staebler RM, Acevedo O, Czikowsky MJ, Dasilva R, Brait E, Miranda V (2004) Landuse change effects on local energy, water, and carbon balances in an Amazonian agricultural field. Glob Change Biol 10:895-907

San José JJ, Montes RA (2001) Management effects on carbon stocks and fluxes across the Orinoco savannas. For Ecol Manage 150:293-311

Scott NA, Tate KR, Giltrap DJ, Smith CT, Wilde RH, Newsome PFJ, Davis MR (2002) Monitoring land-use change effects on soil carbon in New Zealand: quantifying baseline soil carbon stocks. Environ Pollut 116:167-186

Trouve C, Disnar JR, Mariotti A (1996) Changes in the amount and distribution of neutral monosaccharides of savannah soils after plantation of Pinus and Eucalyptus in the Congo. Eur $\mathbf{J}$ Soil Sci 47:51-59

Wang J, Fu B, Qiu Y, Chen LD (2001) Soil Nutrients in relation to land uses and landscape position in the semi-arid small catchment on the Loess Plateau in China. J Arid Environ 48:537-550

Wu HB, Guo ZT, Peng CH (2003) Land use induced changes of organic carbon storage in soils of China. Glob Change Biol 9:305-315

Wu JG, Zhang XQ, Xu DY (2004) The mineralization of soil organic carbon under different land uses in the Liupan mountain forest zone (Chinese with English abstract). Acta Phytoecol Sin 28(4):530-538

Xu Y, Tian JL (2004) The evaluating method of eco-environment restoration pattern: a case study of the loess hilly-gully region (Chinese with English abstract). Acta Geogr Sin 59:621-628

$\mathrm{Xu}$ XL, Zhang KL, Xu XL, Peng WY (2003) Spatial distribution and estimating of soil organic carbon on Loess Plateau (Chinese with English abstract). J Soil Water Conserv 17(3):13-15

Zak DR, Grigal DF, Gleeson S, Tilman D (1990) Carbon and nitrogen cycling during old-field succession: constraints on plant and microbial biomass. Biogeochemistry 11:111-129

Zhang F (1991) Character of ecological position and the coping disposition of plant (Chinese with English abstract). Acta Conserv Soliet Aquae Sin 5(2):46-51

Zhang MK, He ZL (2004) Long-term changes in organic carbon and nutrients of an Ultisol under rice cropping in southeast China. Geoderma 118:167-179

Zhang XQ, Xu DY (2003) Potential carbon sequestration in China's forests. Environ Sci Policy 6:421-432

Zhao SL, Li FM, Wang J (1995a) Discussion on development of water-harvested agriculture in semi-arid region Northwest China (Chinese with English abstract). Acta Bot Boreali-Occident Sin 15(8):9-12

Zhao SL, Wang J, Li FM (1995b) A study on the limitation of agriculture development by conserving soil and water in semiarid regions of Loess Plateau (Chinese with English abstract). Acta Bot Boreali-Occident Sin 15(8):13-18 